\title{
NALEŻYTA STARANNOŚĆ CZŁONKÓW ORGANU ZARZĄDZAJĄCEGO SPÓŁKI KAPITAŁOWEJ
}

\section{Abstract \\ Due diligence of members of the management body of a capital company}

A limited company through appointing a member of its body expects that the function thereof shall be performed with due diligence and in line with a professional nature of the activity which shall demonstrate the level higher than the average. In this scope, the establishment of the requirements will be possible through determining a "diligent guardian" model. The activity performed by a member of the management body who does not keep to this model, shall result in liability for damages. In the case of a member of the Management Board, the increased standard of care shall apply in the evaluation of the fault under Art. 293 (1) of the Commercial Companies Code.

Słowa kluczowe: odpowiedzialność cywilnoprawna członka zarządu spółki komunalnej, należyta staranność, model starannego piastuna

Keywords: civil liability of a member of the management board of a municipal company, due diligence, a model of a diligent supervisor

ASJC: 3308, JEL: K31

Zarząd spółki kapitałowej ma szerokie kompetencje w zakresie prowadzenia spraw spółki kapitałowej i jej reprezentacji. Mając na uwadze, że celem działalności spółki kapitałowej z reguły jest osiągnięcie sukcesu gospodarczego, z wykonywaniem mandatu członka organu spółki wiąże się nie tylko znajomość przepisów prawnych, w tym zasad prowadzenia działalności gospodarczej, lecz także właściwego prowadzenia spraw spółki. Słusznie w literaturze podkreślono, że regulacje ustawy z dn. z 15 września 2000 r. - Kodeks spółek handlowych (Dz.U. 2019, poz. 505 tekst jedn., dalej: „Kodeks spółek handlowych”, „k.s.h.”), które określają podstawowe kompetencje każdego z organów (art. $201 \$ 1$ i art. $368 \$ 1$ k.s.h. w odniesieniu do zarządu i art. $219 \$ 1$ oraz art. $382 \$ 1$ k.s.h. w odniesieniu do rady nadzorczej) - a tym samym obowiązki członków tych organów - zawierają implicite wymóg ich wykonywania z należytą starannością (Opalski, Oplustil 2013b, s. 17). Mowa tutaj o art. $293 \$ 2$ oraz art. $483 \$ 2$ k.s.h. We wskazanych regulacjach prawnych: „Członek zarządu, rady nadzorczej oraz likwidator 
powinien przy wykonywaniu swoich obowiązków dołożyć staranności wynikającej z zawodowego charakteru swojej działalności". Tym samym ustawodawca wprowadził zaostrzone mierniki staranności.

W niniejszym opracowaniu poddano analizie przesłankę „,należytej staranności” jako elementu prawidłowego wykonywania obowiązków członka organu zarządzającego spółką kapitałową. Ustalono zakres tego pojęcia na gruncie prawa cywilnego, a następnie podjęto określenia jego istoty na gruncie Kodeksu spółek handlowych. Poruszono także zagadnienie tzw. business judgement rule, mające wpływ na kształtowanie odpowiedzialności za podejmowanie decyzji biznesowych.

\section{Pojęcie „należytej staranności” na gruncie Kodeksu cywilnego}

W grupie zobowiązań ze świadczeniami działania wyróżnić można zobowiązania rezultatu i starannego działania. Jest to ważne rozróżnienie, wpływa bowiem na ocenę należytego spełnienia świadczenia przez dłużnika. Zobowiązanie rezultatu polega na tym, że dłużnik powinien uzyskać oznaczony i sprecyzowany od początku rezultat. W zobowiązaniu starannego działania dłużnik musi dołożyć należytej staranności w zmierzaniu do określonego celu, natomiast samo uzyskanie tego celu jest poza treścią stosunku zobowiązaniowego. Dłużnik zatem nie ma obowiązku osiągnięcia celu, a jego powinnością jest staranne zachowanie (Rzetecka-Gil 2011, art. 353 k.c.).

Istota zobowiązania starannego działania jest przedmiotem zainteresowania orzecznictwa. I tak Sąd Administracyjny w Lublinie stwierdza (wyrok z 19 sierpnia 2015 r., III AUa 404/15, LEX nr 1793861), że jeżeli osiągnięcie rezultatu określonego w celu zawarcia umowy uzależnione jest także od innych mających nastąpić zdarzeń oraz czynników zewnętrznych leżących poza oddziaływaniem dłużnika, to $\mathrm{z}$ reguły podejmuje on zobowiązanie starannego działania. W zobowiązaniach starannego działania podjęcie przez dłużnika wymaganych czynności przy zachowaniu wiążącego go stopnia staranności oznacza, że dłużnik wykonał zobowiązanie, pomimo iż nie osiągnięto określonego celu umowy (por. wyrok SA w Łodzi z 24 stycznia 2013 r., III AUa 837/12, LEX nr 1293109). Z kolei według Sądu Najwyższego (wyrok z 31 stycznia 2017 r., I UK 488/15, LEX nr 2258059) kwalifikowanie zobowiązań jako umów starannego działania (zlecenia) musi mieć swe racjonalne granice. Nie chodzi o uznanie, bo zlecenie i dzieło to umowy całkowicie odrębne w systemie prawa. Nie decyduje nazwa umów, lecz przedmiot zobowiązania. Jeśli zleceniobiorca ma pracować, wykonując powtarzalne, podobne i takie same z reguły proste czynności, z reguły chodzi o umowę o świadczenie usług. Cechą istotną umowy jest wówczas staranność w wykonywaniu czynności. Wynikiem takiej staranności nie musi być rezultat, który jest dziełem. Nie znaczy to, że zleceniobiorca, podobnie jako pracownik w stosunku pracy, nigdy nie wykonują trwałego produktu. Jednak wówczas inne są obowiązki i prawa stron, to znaczy: wynagrodzenie jest należne, nawet gdy wynik pracy nie jest taki, jaki był zakładany przez zleceniodawcę, o ile zachowano wymaganą staranność. Na tym tle różnica w porównaniu z umową o dzieło wyraża się w tym, że 
jej przedmiotem jest wykonanie dzieła, $\mathrm{z}$ reguły jednostkowego, indywidualnego, na odpowiedzialność i ryzyko wykonawcy, czyli przy spełnieniu parametrów i wymagań określonych lub właściwych dla przedmiotu zamówienia.

Należytą staranność system prawny wskazuje jako kryterium oceny zachowania podmiotu, któremu chcemy przypisać odpowiedzialność z tytułu niewykonania lub nienależytego wykonania zobowiązania albo dopuszczenia się czynu niedozwolonego. W obu przypadkach chodzi o ocenę strony podmiotowej, gdy stwierdzony już został fakt w postaci niewykonania (nienależytego wykonania) zobowiązania lub deliktu. Nie polega to jednak na ustaleniach co do stanu psychicznego podmiotu, ale na dokonaniu zobiektywizowanej oceny jego postawy (dbałości, rozwagi), jej jakości (Olejniczak 2014).

Dokonanie kwalifikacji konkretnego działania z punktu widzenia zachowania "należytej staranności” nie wydaje się możliwe bez oddzielenia zachowań (zaniechań) dłużnika od oceny tych zachowań w świetle kryterium dochowania należytej staranności (Opalski, Oplustil 2013b, s. 15, wraz z przyw. literaturą). Należyta staranność dłużnika zawsze musi być odniesiona do określonego zachowania, do którego dłużnik ten jest zobowiązany zgodnie z treścią stosunku obligacyjnego (Jastrzębski 2013, s. 17, wraz z przyw. literaturą). Ocena należytej staranności następuje bowiem według rodzaju danego stosunku, a więc na podstawie istniejących w ramach danego stosunku i środowiska norm pozaprawnych oraz okoliczności mających charakter zewnętrzny względem stron (Banaszczyk, Granecki 2002, s. 15-16). Problem powstaje przede wszystkim wówczas, gdy mamy do czynienia ze zobowiązaniami starannego działania, w których treść stosunku nie jest opisana przez wskazanie enumeratywnego katalogu zachowań ani przez oznaczenie rezultatu, do którego doprowadzić ma dłużnik, lecz przez odwołanie się do abstrakcyjnego wzorca postępowania (np. adwokata, lekarza, członka zarządu). Wówczas bowiem zachowania dłużnika, które będą odbiegać od tego wzorca (np. niezłożenie środka odwoławczego, zaniedbanie procedury medycznej, nieuzasadnione ekonomicznie przerwanie negocjacji handlowych), będą stanowić naruszenie stosunku obligacyjnego (Jastrzębski 2013, s. 17, wraz z przyw. literaturą). Dopiero po ustaleniu takiego nienależytego wykonania zobowiązania przechodzimy do badania kwestii należytej staranności w celu udzielenia odpowiedzi na pytanie, czy dłużnik powinien ponosić odpowiedzialność za skutki nienależytego wykonania zobowiązania. Może się bowiem okazać, że naruszenie zasad postępowania (np. niezłożenie środka odwoławczego lub przerwanie negocjacji) wynika z przyczyn, za które dłużnik nie powinien ponosić odpowiedzialności (np. został wprowadzony w błąd albo nagła choroba uniemożliwiła mu kontynuowanie czynności; por. Jastrzębski 2013, s. 17, wraz z przyw. literaturą). Tym samym wierzyciel jest zmuszony udowodnić niedołożenie należytej staranności w celu wykazania niewykonania (nienależytego wykonania) zobowiązania (Opalski, Oplustil 2013b, s. 15, wraz z przyw. literaturą).

Warto w tym miejscu dodać, że przepis art. $355 \$ 2$ ustawy z dn. 23 kwietnia 1964 r. - Kodeks cywilny (Dz.U. 2019, poz. 1145 tekst jedn., dalej: „Kodeks cywilny”, „k.c.") stanowi, że ocena należytej staranności dłużnika w zakresie prowadzonej przez 
niego działalności gospodarczej musi uwzględniać zawodowy charakter tej działalności. W tym przypadku, bez względu na treść zobowiązania, w stosunkach zarówno jednostronnie, jak i obustronnie profesjonalnych zawodowy charakter działalności dłużnika określa obiektywny wzorzec wymaganej staranności (Olejniczak 2014). Istotny wydaje się tutaj podgląd wyrażony przez Sąd Najwyższy w wyroku z 17 stycznia 2017 r. (IV CSK 143/16, LEX nr 2252208). Wynika z niego, że każdego dłużnika obowiązuje należyta staranność (art. $355 \$ 1$ k.c.), a staranność zawodowa nie może być odnoszona do staranności nieprofesjonalisty. Zgodnie z art. $355 \$ 2$ k.c. przedsiębiorca jest zobowiązany do staranności profesjonalisty, a więc osoby zawodowo trudniącej się przedsiębraną działalnością gospodarczą. Także w orzecznictwie ugruntowane zostało stanowisko, zgodnie z którym:

[...] w stosunkach gospodarczych przy określaniu wzorca należytej staranności należy uwzględniać wyższe, surowsze wymagania, $\mathrm{z}$ uwagi na zawodowy charakter działalności dłużnika, prowadzonej w sposób ciągły, co do zasady oparty na szczególnych umiejętnościach, wiedzy i doświadczeniu (wyrok SA w Łodzi z 7 listopada 2017 r., I ACa 697/17, LEX nr 2461450; por. wyrok SA w Białymstoku z 4 marca 2016 r. I ACa 975/15, LEX nr 2016301).

W odniesieniu do stosunków o charakterze zawodowym uzasadnia to wymaganie staranności dłużnika na poziomie wyższym od przeciętnego. Przy tym wymaganie takie należy stosować do umów zarówno jednostronnie, jak i dwustronnie profesjonalnych (wyrok SA w Łodzi z 7 listopada 2017 r., I ACa 697/17, LEX nr 2461450). Uważa się, że profesjonalizm dłużnika powinien przejawiać się $\mathrm{w}$ dwóch podstawowych cechach jego zachowania: postępowaniu zgodnym z regułami fachowej wiedzy oraz sumienności. Wzorzec należytej staranności musi uwzględnić zwiększone oczekiwania co do zawodowych kwalifikacji dłużnika specjalisty, co do jego wiedzy i praktycznych umiejętności korzystania z niej (wyrok SN z 22 września 2005 r., IV CK 100/05, LEX nr 187120). Obok fachowych kwalifikacji od profesjonalisty wymaga się zwiększonego zaangażowania w podjęte działania przygotowujące i realizujące świadczenie. Chodzi o większą zapobiegliwość, rzetelność, dokładność w działaniach dłużnika profesjonalisty w stosunku do podmiotów, które nie wykonują zobowiązania w ramach swojej działalności gospodarczej. Jednak należyta staranność osoby zawodowo wykonującej zobowiązanie jest rozumiana jako przeciętnie wymagana, a więc zachowująca ustaloną wzorcem średnią na wystarczającym poziomie, na tyle dobrym, aby prawidłowo wykonać czynności zawodowe (wyrok SN z 15 marca 2012 r., I CSK 330/11, LEX nr 1147729; wyrok SA w Białymstoku z 14 lutego 2018 r. I AGa 30/18, LEX nr 2535407). Z zasady nawet od profesjonalisty nie jest więc wymagane dołożenie staranności na możliwie najwyższym poziomie. Przy ustalaniu wzorca należytej staranności dłużnika w zakresie prowadzonej przez niego działalności gospodarczej (używa się także określenia „szczególna staranność") korzysta się z informacji zawartych w pragmatykach zawodowych, standardach formalnie obowiązujących dla określonych kierunków kształcenia, a także ze zbiorów norm formułowanych w ramach poszczególnych grup zawodowych, które 
określają właściwe dla danego środowiska zachowania (kodeksy etyczne, zbiory dobrych obyczajów itp.; por. Olejniczak 2014).

Prowadzenie działalności profesjonalnej uzasadnia zwiększone oczekiwania co do umiejętności, wiedzy oraz skrupulatności osoby ją prowadzącej. W obrocie gospodarczym powinno się stosować bardziej rygorystyczne wymagania odnośnie do sporządzania umów. Badanie zgodnego zamiaru stron będących profesjonalistami, odmiennego co do istotnych postanowień umowy od tekstu pisemnego, godziłoby w bezpieczeństwo obrotu. Jeżeli zatem przedsiębiorcy profesjonaliści podpisują umowę, mają, a przynajmniej powinni mieć świadomość, jakie prawa im przysługują i jakie obowiązki na siebie przyjmują (wyrok SA w Białymstoku z 4 marca 2016 r., I ACa 975/15, LEX nr 2016301).

W świetle powyższych ustaleń osoba prowadząca działalność zawodową musi zdawać sobie sprawę, że oczekiwania co do profesjonalizmu, czyli posiadanych umiejętności i kompetencji, będą kształtować się inaczej niż wobec osoby, która nie świadczy usług w takim charakterze. Podejmowanie czynności świadczących o niedostatecznych kwalifikacjach, niezgodnych z wypracowanymi i stosowanymi standardami, może być podstawą zarzutu niedołożenia należytej staranności.

\section{Istota należytej staranności członków organu zarządzającego spółki kapitałowej}

Należyte wypełnienie obowiązku prowadzenia spraw spółki (czy - analogicznie wykonywania nadzoru; art. $219 \$ 1$, art. 221 i art. $382 \$ 1$ k.s.h.) trzeba oceniać przez pryzmat art. $293 \$ 2$ i art. $483 \$ 2$ k.s.h., które przewidują obowiązek przestrzegania zobiektywizowanego wzorca postępowania członka organu (Opalski, Oplustil 2013a, s. 28, wraz z przyw. literaturą). Obiektywny miernik należytej staranności statuują właśnie art. $293 \$ 2$ i art. $483 \$ 2$ k.s.h. (Opalski, Oplustil 2013b, s. 17, wraz z przyw. literaturą). Wskazane przepisy Kodeksu spółek handlowych określają profesjonalny wzorzec staranności, zaostrzając zasady odpowiedzialności w stosunku do modelu należytej staranności wynikającej z art. $355 \$ 1$ k.c. Podwyższenie wymagań wiąże się z zawodowym charakterem wykonywanej działalności i polega na obowiązku posiadania odpowiedniego poziomu wiedzy oraz doświadczenia (Okolski, Wajda 2007, s. 11; Guzewicz, Jagodziński 2013, s. 49, wraz z przyw. literaturą). Określenie abstrakcyjnej miary staranności ma takie znaczenie, że pozwala na skonkretyzowanie poszczególnych czynności faktycznych i prawnych, które ciążą na dłużniku, oraz sposobu ich wykonania. Oznacza to, że o ile obowiązki w znaczeniu abstrakcyjnym (obowiązek pozyskania kapitału, racjonalizacji zatrudnienia, poszukiwania nowych rynków itp.) określane są na podstawie art. 56 i art. $354 \$ 1$ k.c., o tyle konkretne zachowanie wymagane od członków organu w danych okolicznościach faktycznych będzie determinowane na podstawie standardu należytej staranności. Jego niepodjęcie będzie zatem stanowiło naruszenie treści stosunku prawnego pomiędzy członkiem organu a spółką. Innymi 
słowy niepodjęcie określonych czynności, które podjąłby abstrakcyjny wzorzec działający z należytą starannością, będzie stanowiło naruszenie zobowiązania (Hotel 2015, s. 83-84, wraz z przyw. literaturą). Słuszny zatem wydaje się pogląd Marcina Hotela (2015, s. 85, wraz z przyw. literaturą), według którego miara należytej staranności będzie się różnić w zależności od konkretnych okoliczności (typ spółki, rodzaj działalności, jej zakres itp.). W wyroku z 24 marca 2015 r. (II UK 167/14, LEX nr 1941825) Sąd Najwyższy wyraźnie podkreśla powyższą relację - z racji statusu członkowi zarządu spółki kapitałowej należy przypisać miarę podwyższonej staranności, co wynika jednoznacznie $\mathrm{z}$ art. $293 \$ 2$ k.s.h. Także $\mathrm{w}$ doktrynie kwestia ustalenia sposobu rozumienia należytej staranności członka organu zarządzającego przy podejmowaniu czynności w ramach wykonywania mandatu została podjęta. Stwierdzono, że:

[...] istotą, sensem i podstawową treścią stosunku członkostwa w organie jest nałożenie na mandatariusza nakazu postępowania w sposób odpowiednio staranny, co pozwala zaspokoić interes spółki jako wierzyciela. Obowiązek starannego wykonywania mandatu jest ustawowym elementem korporacyjnego stosunku organizacyjnego łączącego członka zarządu (rady nadzorczej) ze spółką (Opalski, Oplustil 2013b, s. 17).

Spółka kapitałowa, która powołuje określoną osobę na członka zarządu (członka organu spółki - przyp. D.F.), ma bowiem prawo spodziewać się, że osoba ta będzie wypełniała obowiązki wynikające z powierzonego jej statusu w prawidłowy sposób - a więc zgodnie z interesem spółki i ze starannością wynikającą z zawodowego charakteru jej działalności (Bielecki 2005, s. 20). Funkcją art. $293 \$ 2$ k.s.h. jest bowiem podkreślenie wymagania profesjonalizmu po stronie członka organów spółki odpowiedzialnego za realizację interesu spółki jako autonomicznego podmiotu prawa (Michalski 2018, art. 293 k.c., wraz z przyw. literaturą).

\section{Wzorzec „starannego piastuna” na gruncie Kodeksu spółek handlowych}

Wynikający z art. $293 \$ 2$ i art. $483 \$ 2$ k.s.h. wzorzec „starannego piastuna” ma decydujące znaczenie dla oceny prawidłowości wykonywania funkcji członka danego organu (Opalski, Oplustil 2013b, s. 18). Przyjmując wzorzec (określany w doktrynie mianem przeciętnego członka zarządu, który dochowuje staranności generalnie przyjętej w danego typu stosunkach), z którym będziemy porównywali zachowanie danego piastuna, konieczne jest odniesienie się do warunków, w których wykonuje on swoją funkcję, takich jak rozmiar prowadzonej działalności przez spółkę, typ spółki, jej publiczny bądź niepubliczny charakter itp. Innej bowiem staranności będziemy wymagać od członka organu dużej spółki giełdowej, a innej od członka organu małej rodzinnej spółki z o.o. Warto jednak zaznaczyć, że wymóg należytej staranności jest zawsze taki sam, bez znaczenia, kto pełni daną funkcję. Taka sama staranność będzie więc wymagana od 
osoby, która nigdy nie miała do czynienia z zajmowaniem się sprawami spółki, jak i od profesjonalnego menedżera (Hotel 2015, s. 87-88, wraz z przyw. literaturą).

$\mathrm{Na}$ istotny element tworzonego modelu „starannego piastuna” zwraca uwage Adam Opalski i Krzysztof Oplustil. Otóż ich zdaniem problemem polskiego prawa spółek jest luka w interpretacji standardów należytego i starannego wykonywania zadań zarządczych i nadzorczych. W doktrynie ani w orzecznictwie nie wykształcono do tej pory zasad prawidłowego gospodarowania mieniem spółek kapitałowych (zarządzania powierzoną inwestycją). Artykuł $293 \$ 2$ i art. $483 \$ 2$ k.s.h. zobowiązują członków organów do zachowania podwyższonej, profesjonalnej staranności (staranności „wynikającej z zawodowego charakteru swojej działalności”). Formuła ta stanowi jednak wyłącznie klauzulę generalną, wymagającą wypełnienia treścią. Tymczasem ani doktryna, ani orzecznictwo sądowe nie precyzują, jak konkretnie powinni postępować członkowie zarządu i rady nadzorczej w konfrontacji z wyzwaniami, jakie rodzi pełnienie mandatu (np. przy okazji podjęcia ważnej decyzji inwestycyjnej, prowadzenia sporu sądowego przeciwko kontrahentowi, powstania podejrzenia działania przez zarządcę na szkodę spółki). Odpowiedź na pytanie, czy dane postępowanie spełnia standardy należytego i starannego wykonywania zadań, jest w praktyce udzielana w zasadzie wyłącznie „intuicyjnie”. Wprawdzie funkcjonariusze spółek muszą sobie radzić z bardzo zróżnicowanymi sytuacjami, a bogactwo stanów faktycznych jest funkcją złożoności i stopnia skomplikowania współczesnego obrotu gospodarczego, to jednak istnieje możliwość stypizowania stanów faktycznych i określenia co najmniej ramowych standardów zachowań funkcjonariuszy w poszczególnych grupach przypadków. Zabiegi interpretacyjne zmierzające w tym kierunku są podejmowane w doktrynie i orzecznictwie rozwiniętych porządków prawa spółek (Opalski, Oplustil 2013b, s. 21, wraz z przyw. literaturą).

Na gruncie orzecznictwa dominuje pogląd, zgodnie z którym w odniesieniu do organów obowiązuje swoisty miernik związany z rzetelnością, wiedzą, sumiennością, jaka powinna cechować członków organów (wyrok SA w Krakowie z 12 stycznia 2016 r., I ACa 1413/15, LEX nr 2016314; wyrok SA w Białymstoku z 19 kwietnia 2018 r., I AGa 63/18, LEX nr 2537614). Trafnie tę zależność ujmuje Sąd Najwyższy (wyrok z 26 stycznia 2000 r., I PKN 482/99, OSNP 2001, nr 11, poz. 378). Według niego wzrost zakresu swobody w podejmowaniu decyzji gospodarczych przez członka organu zarządzającego spółki powinien powodować większe oczekiwania co do rzetelności i sumienności oraz troski o interesy spółki ze strony danego członka jej władz. Staranność zarządcy powinna uwzględniać przewidywanie skutków założonych działań, podejmowanie wszelkich dostępnych środków faktycznych lub prawnych w celu wywiązania się ze zobowiązania, a także wykazywanie zapobiegliwości, sumienności, ostrożności i dbałości dla osiągnięcia rezultatu zgodnego z interesami spółki (wyrok SA w Katowicach z 5 listopada 1998 r., I ACa 322/98, OSA 2000, nr 2, poz. 8).

Zdaniem Sądu Apelacyjnego w Krakowie, szczególna staranność - wymagana w $₫ 2$ art. 293 k.s.h. - poddana jest ocenie pod kątem „staranności wynikającej z zawodowego charakteru działalności" (wyrok z 3 września 2013 r., III AUa 962/12, LEX nr 1366100; por. wyrok SN z 24 marca 2015 r., II UK 167/14, LEX nr 1941825; wyrok SA w Krakowie 
z 12 stycznia 2016 r., I ACa 1413/15, LEX nr 2016314; wyrok SA w Łodzi z 15 stycznia 2016 r., I ACa 1003/15, LEX nr 1979415; wyrok SA w Rzeszowie z 10 maja 2017 r., III AUa 852/16, LEX nr 2310585; por. Szajkowski 2002, s. 765; Kidyba 2015, s. 1401 i n.). Sąd wskazuje jednocześnie, że w przepisie tym chodzi o taką szczególną należytą staranność, jakiej oczekuje się od osoby, która prowadzi działalność zawodowo, a w związku z tym jest to staranność na poziomie wyższym od przeciętnego. Nie ma znaczenia, czy odpowiednie kryteria specjalistyczne zostały osiągnięte w drodze wykształcenia, czy też przez odpowiednie przygotowanie praktyczne (wyrok SA w Krakowie z 12 stycznia 2016 r., I ACa 1413/15, LEX nr 2016314). Zastosowanie takiego miernika staranności wyraża się w tym, że od wskazanych osób wymagać należy znajomości przepisów prawa, konsekwencji ich naruszenia, zasad funkcjonowania spółki, swoich praw i obowiązków, zasad wykonywania powierzonych funkcji, procesów organizacyjnych czy zasad zarządzania zasobami ludzkimi (Kidyba, Kopaczyńska-Peczniak 2013, wraz z przyw. literaturą). Profesjonalizm wymagany od członków zarządu spółki kapitałowej, a także wynikająca z niego podwyższona staranność (art. $355 \$ 2$ k.c.) pozwalają na przyjęcie, iż każdy członek zarządu obowiązany jest kontrolować sytuację w spółce przynajmniej z taką uwagą, jaka pozwala na zorientowanie się, że jest ona niewypłacalna i że należy wystąpić z wnioskiem o ogłoszenie upadłości. Wniosek o ogłoszenie upadłości może być uznany za zgłoszony we właściwym czasie, gdy wykazane zostało, że zgłaszając go, zarząd (członek zarządu) uczynił ze swej strony wszystko, by nie dopuścić do zniweczenia celu postępowania upadłościowego poprzez stworzenie sytuacji, w której niektórzy wierzyciele są zaspokajani kosztem innych (wyrok WSA w Poznaniu z 10 maja 2017 r., I SA/Po 1443/16, LEX nr 2296978).

Przy podejmowaniu decyzji dotyczących prowadzenia spraw spółki członek zarządu powinien się kierować wyłącznie jej interesem, a zawinione działania dokonane z przekroczeniem granic ryzyka gospodarczego są sprzeczne z interesem spółki i jako naruszające ogólny nakaz określony w art. 201 k.s.h. uzasadniają odpowiedzialność członka zarządu na podstawie art. $293 \$ 1$ k.s.h. (wyrok SN z 24 lipca 2014 r., II CSK 627/13, LEX nr 1545031). Sąd Najwyższy do działań sprzecznych z interesem spółki zalicza zawarcie umowy pozornej z pełną świadomością, że nie zostanie ona wykonana (wyrok z 24 lipca 2014 r., II CSK 627/13, LEX nr 1545031). Na taką też ocenę zasługuje korzystanie z możliwości swobodnego podejmowania decyzji co do wypłaty środków z kasy spółki, wynikającej z racji pełnienia funkcji prezesa w jej jednoosobowym zarządzie, dla zabezpieczenia realizacji własnych celów, a nie celów związanych z jej działalnością - jest to działanie na szkodę spółki w rozumieniu art. 293 k.s.h. (wyrok SA we Wrocławiu z 12 kwietnia 2012 r., I ACa 920/11, LEX nr 1238517).

Wobec powyższego konsekwentnie należy uznać, że z racji pełnienia funkcji każdy członek zarządu ma obowiązek znać stan spółki, czynnie uczestnicząc w zarządzaniu. Odpowiedzialności w omawianym trybie nie może uchylić umowa łącząca członków zarządu co do sposobu kierowania sprawami spółki, w szczególności ustalony umownie podział czynności. Tego rodzaju umowa ma znaczenie tylko wewnątrzorganizacyjne, nie niweczy skutków z art. $204 \$ 1$ k.s.h. i nie może wyłączyć odpowiedzialności 
odszkodowawczej członka zarządu wynikającej z bezwzględnie obowiązującego art. 299 $\$ 1$ k.s.h. (wyrok SA w Łodzi z 31 stycznia 2019 r., I AGa 269/18, LEX nr 2637821; por. wyrok SN z 15 maja 2014 r., II CSK 446/13, LEX nr 1480163). Jak zaznacza Sąd Najwyższy: nie wyłącza odpowiedzialności członka zarządu nieznajomość stanu finansów spółki (wyrok z 24 marca 2015 r., II UK 167/14, LEX nr 1941825) czy też subiektywna ocena sytuacji majątkowej spółki, a w szczególności nadzieja na przyszłe wpływy i zyski (por. wyrok SA w Rzeszowie z 10 maja 2017 r., III AUa 852/16, LEX nr 2310585).

\section{Koncepcja biznesowej oceny sytuacji (business judgement rule)}

Podejmowanie decyzji biznesowych wiąże się nieodłącznie z ryzykiem narażenia spółki na straty, a w skrajnym przypadku - doprowadzenia do jej niewypłacalności i upadłości. Jednocześnie jednak zbyt asekuracyjne zachowania menedżerów nie leżą w interesie spółki ani wspólników, gdyż osłabiają jej konkurencyjność i zdolność do wypracowania zysków. W uwarunkowaniach gospodarki rynkowej podejmowanie ryzyka biznesowego jest niezbędnym warunkiem osiągnięcia sukcesu w skali nie tylko poszczególnych spółek, ale też gospodarki jako całości. Dlatego system prawny powinien $\mathrm{z}$ jednej strony zapewnić spółce i wspólnikom ochronę przed nadużyciami oraz niestarannym i nielojalnym wypełnianiem mandatu przez piastunów, a zarazem z drugiej strony stworzyć tym ostatnim „bezpieczną przystań” (safe harbor), chroniąc ich przed odpowiedzialnością z tytułu decyzji gospodarczych obarczonych ryzykiem powstania szkody spółki, jednak potencjalnie będących źródłem znacznych korzyści (Opalski, Oplustil 2013b, s. 20).

W odniesieniu do członków organów spółek zagadnienie to wiąże się ściśle z tzw. zasadą biznesowej oceny sytuacji (business judgement rule; Hotel 2015, s. 85, wraz z przyw. literaturą). Jej istotą jest zwolnienie menedżerów od odpowiedzialności za skutki podjętych przez nich decyzji gospodarczych, które ex post okazały się błędne i szkodliwe dla spółki, jeżeli przy ich podejmowaniu zarządcy przestrzegali minimalnego standardu staranności (tzw. standard of conduct), w szczególności w zakresie uzyskania dostępu do informacji istotnych dla podjęcia wystarczająco przemyślanej decyzji oraz analiz dotyczących ryzyka, kierując się przy tym racjonalnie pojmowanym interesem spółki, a jednocześnie nie znajdowali się w konflikcie interesów (Błaszczyk 2012, s. 75). Inaczej mówiąc, zarządzający mają prawo do błędu, jeżeli zostały zachowane cztery przesłanki prawidłowości decyzji biznesowej:

- brak konfliktu interesów między menedżerem a interesem spółki;

- przed podjęciem decyzji menedżer uzyskał wystarczające informacje o okolicznościach istotnych dla podjęcia decyzji, jakie mógł uzyskać w danej sytuacji, oraz przeanalizował skutki podjęcia innej decyzji biznesowej (ten element nie wyklucza asymetrii informacyjnej wynikającej z presji czasu, polegania na opiniach eksperckich, braku dostępności lub nadmiernej trudności w dostępności do informacji); 
- racjonalne przekonanie, że decyzja leży w najlepszym interesie udziałowców spółki;

- decyzja nie narusza prawnie chronionych interesów interesariuszy spółki kapitałowej (Buszmak 2017, s. 42, wraz z przyw. literaturą).

Tym samym należy przyjąć, że:

[...] jeżeli przy podejmowaniu konkretnej decyzji biznesowej osoby zarządzające spełniły określone standardy postępowania w zakresie staranności i lojalności względem spółki, wyłączona jest ich odpowiedzialność za szkodliwe następstwa danej decyzji, a sąd nie dokonuje de novo jej oceny od strony celowości i opłacalności (Buszmak 2017, s. 42, wraz z przyw. literaturą).

Trzeba przy tym cały czas pamiętać - co szczególnie akcentuje Dawid Buszmak - że okoliczność, czy decyzja w wyniku dalszego biegu zdarzeń (już po jej podjęciu) okazała się obiektywnie ekonomicznie niekorzystna, nie ma w ogóle znaczenia, istotna jest bowiem jedynie ocena ex ante (z naciskiem na przebieg procesu decyzyjnego). Odrzucenie perspektywy ex post oznacza zaś, że przy ocenie decyzji menedżerskiej sąd powinien zredukować stan wiedzy o faktach do momentu i okoliczności podjęcia danego rozstrzygnięcia gospodarczego (postawić się na miejscu zarządcy, uwzględniając zasób wiedzy, jaką dysponował lub mógł i powinien był dysponować). Przykładowo należy wskazać, że od zarządcy spółki nie można wymagać przy podejmowaniu strategicznej decyzji inwestycyjnej zachowania reguł ostrożności uwzględniających szczególne warunki kryzysu gospodarczego (crisis lesson), gdy sama decyzja była podjęta przed jego rozpoczęciem, a menedżer nie mógł wiedzieć, że za kilka tygodni dojdzie do załamania na światowych rynkach, co uczyni jego decyzję z perspektywy czasu błędną (Buszmak 2017, s. 45, wraz z przyw. literaturą). Jest również oczywiste, że członek zarządu nie ma w zwykłej sytuacji wpływu na - czasami zupełnie nieprzewidywalne - zachowania innych uczestników obrotu, nie wspominając już o czynnikach makroekonomicznych. Należy zatem przesunąć środek ciężkości oceny ze skutku (zawarcie niekorzystnej umowy) na sam proces dochodzenia do niego (np. zapoznanie się z danymi rejestrowymi kontrahenta, sprawdzenie, czy w księdze wieczystej prowadzonej dla nabywanej nieruchomości nie są wpisane obciążenia, sprawdzenie sytuacji finansowej kontrahenta, zlecenie sporządzenia ekspertyzy technicznej czy opinii prawnej, zapoznanie się z dokumentacją techniczną, konsultacja $\mathrm{z}$ innymi członkami zarządu, uzyskanie zgody organu spółki wymaganej przez ustawę lub umowę na dokonanie danej czynności, dokonanie symulacji kosztów, analiza alternatywnych możliwości postępowania, zwrócenie się do tzw. wywiadowni gospodarczej). Z punktu widzenia koncepcji biznesowej oceny sytuacji nie jest istotne, czy określona decyzja okazała się z perspektywy czasu nieopłacalna lub wręcz szkodliwa, lecz to, czy sam proces decyzyjny przebiegał w sposób nienaruszający treści stosunku korporacyjnego (spółka - członek zarządu) oraz czy nie został naruszony obowiązek lojalności (Buszmak 2017, s. 42-43, wraz z przyw. literaturą). 


\section{Istota staranności będącej obowiązkiem pracownika} na gruncie art. $100 \S 1$ k.p.

Obowiązki pracownika składają się na treść stosunku pracy. Ustawodawca jasno określił główny obowiązek pracownika w art. 22 ustawy z dn. 26 czerwca 1974 r. - Kodeks pracy (Dz.U. 2019, poz. 1040 tekst jedn. ze zm., dalej: „Kodeks pracy”, „k.p.”): wykonywanie pracy określonego rodzaju na rzecz pracodawcy i pod jego kierownictwem oraz w miejscu i czasie wyznaczonym przez pracodawcę. Treść tego zobowiązania sprecyzowana została w art. 100 k.p., który wskazuje zwłaszcza na element jakościowy pracy (Majrzak 2015, s. 151). I tak do podstawowych obowiązków pracownika na gruncie art. $100 \$ 1$ k.p. należy wykonywanie pracy sumiennie i starannie oraz stosowanie się do poleceń przełożonych, które dotyczą pracy, jeżeli nie są one sprzeczne z przepisami prawa lub umową o pracę. Warto tutaj podkreślić, że „przepis reguluje najważniejsze obowiązki pracownika, niezależnie od podstawy prawnej nawiązania stosunku pracy” (Majrzak 2015). Pracownik jest zobowiązany do świadczenia pracy w odpowiedniej ilości i o odpowiedniej jakości. Spełnienie tych warunków decyduje, czy praca została wykonana właściwie, tj. w sposób należyty. Miarą należytego wykonania pracy jest sumienność i staranność. Taki sam pogląd reprezentuje Zbigniew Góral (Majrzak 2015, s. 152, wraz z przyw. literaturą).

Nie ma jednego i uniwersalnego kryterium, z wykorzystanie którego można byłoby zbadać staranne wykonywanie pracy (Kuczyński 2008, s. 153; Majrzak 2015, s. 152, wraz z przyw. literaturą). Zarówno doktryna, jak i orzecznictwo zgodnie przyjmują, że pojęcie staranności wskazuje na miarę obiektywną, natomiast sumienne wykonanie pracy wiąże się ze stosowaniem kryteriów subiektywnych, zindywidualizowanych (Majrzak 2015, s. 152, wraz z przyw. literaturą). W tym przypadku bierzemy pod uwagę właściwości osobiste pracownika, takie jak chociażby doświadczenie zawodowe, zdolności psychofizyczne, predyspozycje, posiadane kwalifikacje, wiek czy sprawność. Sumienność oznacza właściwy stosunek do pracy, uwzględniający indywidualne cechy pracownika. Nie musi polegać na maksymalnym angażowaniu się w wykonywaną pracę, ale na takim, które nakazuje rozsądek, posiadana wiedza, siły fizyczne i możliwości intelektualne. Ustawodawca posłużył się w art. $100 \$ 1$ k.p. koniunkcją, dla oceny wykonania zobowiązania pracowniczego konieczne jest bowiem stosowanie kryteriów zarówno obiektywnych, jak i subiektywnych (Góral 2018, art. 100 k.p.).

Swoistą wskazówkę interpretacyjną daje również Sąd Najwyższy, który w wyroku z 8 kwietnia 2009 r. (II PK 260/08, LEX nr 707876) podkreśla, że wykonywanie pracy starannie, zgodnie z art. $100 \$ 1$ k.p., oznacza stosowanie się do reguł technicznych (prakseologicznych) narzucających powinność racjonalnego postępowania, to znaczy do reguł „dobrej roboty”, uwzględniającej reguły wiedzy praktycznej i - w zależności od rodzaju pracy - również naukowej.

Także według innych autorów kryterium staranności pracowniczej odwołuje się do obiektywnych reguł wiedzy i doświadczenia, które określają najbardziej właściwy sposób postępowania przy wykonywaniu danego rodzaju pracy (Dzienisiuk, Skoczyński 2017, 
art. 100 k.p.). Na przykład Sąd Najwyższy uznał, że nie można dopatrzyć się zawinionego niedopełnienia przez radcę prawnego obowiązku pracowniczego $\mathrm{w}$ tym, że nie wniósł odwołania od niekorzystnego orzeczenia, mając na względzie istniejące w tym czasie rozbieżne orzecznictwo w zakresie wykładni przepisów prawa (wyrok SN z 12 czerwca 1975 r., I PR 415/74, OSNC 1976, nr 4, poz. 87).

Wymaga podkreślenia, że nie istnieje ogólny wzorzec staranności pracowniczej (Dzienisiuk, Skoczyński 2017, art. 100 k.p.). Wzorce staranności są zróżnicowane w zależności od rodzaju pracy (Góral 2018, art. 100 k.p.), które odnoszone są do pracowników wykonujących określony zawód czy zajmujących określone stanowiska (Majrzak 2015, s. 152, wraz z przyw. literaturą). Biorąc to pod uwagę, należy dojść do wniosku, że innej staranności można wymagać od pracownika zajmującego stanowisko kierownicze, innej od osoby wykonującej wysoko kwalifikowaną pracę o dużym zakresie samodzielności, a jeszcze innej od pracownika wykonującego proste prace techniczne (Góral 2018, art. 100 k.p.).

Sumienne i staranne wykonywanie pracy można utożsamiać ze „zwyczajnym” wykonywaniem obowiązków. Jeśli zatem systematycznie, w regularnych odstępach czasu za takie właśnie wykonywanie obowiązków było pracownikowi wypłacane świadczenie pieniężne, nazwane w przepisach wewnątrzzakładowych "premią uznaniową, to należy stwierdzić, że jest to składnik wynagrodzenia za pracę o roszczeniowym charakterze (wyrok SN z 5 grudnia 2016 r., III PK 30/16, LEX nr 2191473).

Staranne wykonywanie pracy oznacza również dołożenie przez pracownika staranności ogólnie wymaganej stosownie do rodzaju pracy. Inaczej mówiąc, chodzi tu o postępowanie pracownika zgodne ze wzorcem należycie wykonującego pracę na przykład: lekarza, dyrektora, kierowcy. Wzorce te tworzone są przez społeczeństwo, w tym w szczególności przez sądy, które oceniają zachowanie pracownika, porównując je ze wzorcem, tj. hipotetycznym pracownikiem należycie wykonującym swoje obowiązki (dokładającym należytej staranności). Dokonując tego porównania, nie uwzględnia się cech indywidualnych pracownika (np. wieku, kwalifikacji), bierze się natomiast pod uwagę całokształt okoliczności faktycznych, w których pracownik wykonywał swoje obowiązki (Maniewska 2019, art. 100 k.p.). Najwyższe wymagania stawiane są jednak pracownikom na stanowiskach kierowniczych i samodzielnych. Od nich oczekuje się nie tylko wykonywania poleceń, ale także działania z własnej inicjatywy, jeżeli wymagają tego okoliczności (Maniewska 2019, art. 100 k.p.).

Członkowie zarządu (spółki komunalnej - przyp. D.F.) zobowiązani są do szczególnej staranności i rzetelności przy wykonywaniu obowiązków pracowniczych, a naruszenie tego standardu uzasadnia wypowiedzenie umowy o pracę (Sadlik 2009, s. 23-24).

Podsumowując, położenie przez ustawodawcę nacisku na wykonywanie obowiązków związanych z mandatem członka organu zarządzającego spółki kapitałowej ze szczególną starannością należy ocenić pozytywnie. Podejmowanie bowiem decyzji biznesowych jest immamentnie związane z prowadzeniem spraw spółki i jej reprezentacją, a to wymaga szczególnych umiejętności i staranności członka zarządu. Jest to istotne z tego względu, że wiele czynności podejmowanych jest w warunkach braku pełnej wiedzy, informacji o ich 
konsekwencjach dla spółki, w warunkach ryzyka gospodarczego. Dlatego członek zarządu starannie wykonujący swoje obowiązki nie będzie podejmował nadmiernie ryzykownych działań, ale równocześnie wykazywać się będzie ekspansywnością warunkującą rozwój spółki i jej sukces gospodarczy.

\section{Bibliografia}

Banaszczyk Z., Granecki P. (2002) O istocie należytej staranności, „Palestra”, nr 7-8.

Bielecki M. (2005) Podstawowe przejawy obowiązywania zasady lojalności, „Prawo Spółek”, nr 4. Błaszczyk P. (2012) Koncepcja „biznesowej oceny sytuacji” na tle prawa polskiego. Uwagi de lege lata i de lege ferenda, „Państwo i Prawo”, nr 3.

Buszmak D. (2017) Regulacja odpowiedzialności odszkodowawczej członków zarządu z perspektywy zasad ładu korporacyjnego - uwagi polemiczne, „Przegląd Prawa Handlowego”, nr 2.

Dzienisiuk D., Skoczyński J. (2017) [w:] L. Florek (red.), Kodeks pracy: komentarz, LEX.

Góral Z. (2018) [w:] K.W. Baran (red.), Kodeks pracy: komentarz, LEX.

Guzewicz A., Jagodziński M. (2013) Przesłanki odpowiedzialności członków zarządu w świetle art. 293 k.s.h. i art. 483 k.s.h. - de lege lata i de lege ferenda, „Przegląd Prawa Handlowego”, nr 3.

Hotel M. (2015) Modyfikacja zasad odpowiedzialności członków organów wobec spółki kapitałowej, „Przegląd Sądowy”, nr 9.

Jastrzębski J. (2013) W sprawie odpowiedzialności członków organów spółek kapitałowych, „Przegląd Prawa Handlowego”, nr 7.

Kidyba A. (2015) Kodeks spółek handlowych, t. 1, Warszawa.

Kidyba A., Kopaczyńska-Peczniak K. (2013) Odpowiedzialność cywilnoprawna [w:] A. Kidyba (red.), Spółka z ograniczoną odpowiedzialnością, LEX.

Kuczyński T. (2008) Obowiązki pracownika [w:] Z. Kubot, T. Kuczyński, Z. Masternak, H. Szurgacz (red.), Prawo pracy, Warszawa.

Majrzak K. (2015) Zakres najważniejszych obowiązków pracownika w świetle przepisów Kodeksu pracy, „Prawo Kanoniczne”, nr 1.

Maniewska E. (2019) [w:] K. Jaśkowski, E. Maniewska, Kodeks pracy: komentarz, LEX.

Michalski M. (2018) [w:] A. Kidyba (red.), Kodeks spółek handlowych, t. 2: Komentarz do art. 151-300, LEX.

Okolski J., Wajda D. (2007) Odpowiedzialność członków zarządu spółek kapitałowych, „Przegląd Prawa Handlowego", nr 2.

Olejniczak A. (2014) [w:] A. Kidyba (red.), Kodeks cywilny: komentarz, t. 3: Zobowiązania część ogólna, LEX.

Opalski A., Oplustil K. (2013a) Jeszcze w sprawie odpowiedzialności członków organów spółek kapitałowych, „Przegląd Prawa Handlowego”, nr 12.

Opalski A., Oplustil K. (2013b) Niedochowanie należytej staranności jako przesłanka odpowiedzialności cywilnoprawnej zarządców spółek kapitałowych, „Przegląd Prawa Handlowego”, nr 3.

Rzetecka-Gil A. (2011) [w:] A. Rzepecka-Gil, Kodeks cywilny. Komentarz. Zobowiązania - część ogólna, LEX. 
Sadlik R. (2009) Wypowiedzenie członkowi zarządu spółki z o.o., „Służba Pracownicza”, nr 12.

Szajkowski A. (2002) [w:] S. Sołtysiński S. i in., Kodeks spółek handlowych: komentarz, t. 2, Warszawa.

\section{Orzecznictwo}

Wyrok SA w Białymstoku z 4 marca 2016 r., I ACa 975/15, LEX nr 2016301. Wyrok SA w Białymstoku z 14 lutego 2018 r., I AGa 30/18, LEX nr 2535407. Wyrok SA w Białymstoku z 19 kwietnia 2018 r., I AGa 63/18, LEX nr 2537614. Wyrok SA w Katowicach z 5 listopada 1998 r., I ACa 322/98, OSA 2000, nr 2, poz. 8. Wyrok SA w Krakowie z 3 września 2013 r., III AUa 962/12, LEX nr 1366100. Wyrok SA w Krakowie z 12 stycznia 2016 r., I ACa 1413/15, LEX nr 2016314. Wyrok SA w Lublinie z 19 sierpnia 2015 r., III AUa 404/15, LEX nr 1793861. Wyrok SA w Łodzi z 24 stycznia 2013 r., III AUa 837/12, LEX nr 1293109. Wyrok SA w Łodzi z 15 stycznia 2016 r., I ACa 1003/15, LEX nr 1979415. Wyrok SA w Łodzi z 7 listopada 2017 r., I ACa 697/17, LEX nr 2461450. Wyrok SA w Łodzi z 31 stycznia 2019 r., I AGa 269/18, LEX nr 2637821. Wyrok SA w Rzeszowie z 10 maja 2017 r., III AUa 852/16, LEX nr 2310585.

Wyrok SA we Wrocławiu z 12 kwietnia 2012 r., I ACa 920/11, LEX nr 1238517. Wyrok SN z 12 czerwca 1975 r., I PR 415/74, OSNC 1976, nr 4, poz. 87.

Wyrok SN z 26 stycznia 2000 r., I PKN 482/99, OSNP 2001, nr 11, poz. 378. Wyrok SN z 22 września 2005 r., IV CK 100/05, LEX nr 187120. Wyrok SN z 8 kwietnia 2009 r., II PK 260/08, LEX nr 707876. Wyrok SN z 15 marca 2012 r., I CSK 330/11, LEX nr 1147729. Wyrok SN z 15 maja 2014 r., II CSK 446/13, LEX nr 1480163. Wyrok SN z 24 lipca 2014 r., II CSK 627/13, LEX nr 1545031. Wyrok SN z 24 marca 2015 r., II UK 167/14, LEX nr 1941825. Wyrok SN z 5 grudnia 2016 r., III PK 30/16, LEX nr 2191473. Wyrok SN z 17 stycznia 2017 r., IV CSK 143/16, LEX nr 2252208. Wyrok SN z 31 stycznia 2017 r., I UK 488/15, LEX nr 2258059. 